Part One

Normative Approaches 


\title{
Legal Pluralism as a Human Right and/or as a Human Rights Violation
}

\author{
EVA BREMS
}

\section{THE COMPLEX ARCHITECTURE OF INTERNATIONAL HUMAN RIGHTS LAW ${ }^{1}$}

$\mathrm{I}$

NTERNATIONAL HUMAN RIGHTS law can be analysed in terms of legal pluralism. In public opinion, 'human rights' are often portrayed as a clear and homogenous concept. Yet those who work in the field of human rights know that the reality is very different. A seemingly simple question such as 'show me the list of all human rights' or 'draft me a list of all human rights' is certain to generate as many different lists as there are human rights experts. Indeed, there is no such thing as a single human rights catalogue. Instead, human rights are found in a multitude of highly diverse sources. Even if we leave aside domestic legal sources and focus only on international human rights law, we are dealing with a complex, multilayered reality. The sources and mechanisms of international human rights law can be differentiated along several lines.

In the first place, sources and mechanisms can be categorised on the basis of the governance level at which they operate. At the universal level, human rights standards have been set by the United Nations ${ }^{2}$ and a number

\footnotetext{
1 For a more extensive discussion, see Brems (2014).

2 The main ones are the Universal Declaration of Human Rights (1948), the International Covenant on Civil and Political Rights (1966), the International Covenant on Economic, Social and Cultural Rights (1966), the International Convention on the Elimination of All Forms of Racial Discrimination (1966), the Convention on the Elimination of All Forms of Discrimination Against Women (1979), the Convention against Torture and other Cruel, Inhuman or Degrading Treatment or Punishment (1984), the Convention on the Rights of the Child (1989), the International Convention on the Protection of the Rights of all Migrant Workers and Members of their Families (1990), the International Convention for the Protection of All Persons from Enforced Disappearance (2006), and the Convention on the Rights of Persons with Disabilities (2008).
} 
of specialised agencies such as Unesco ${ }^{3}$ and the International Labour Organization. ${ }^{4}$ Additional-and largely overlapping in terms of contentstandards have been set by regional and subregional organisations, in particular the Council of Europe,${ }^{5}$ the European Union, ${ }^{6}$ the Organization of American States, ${ }^{7}$ the African Union, ${ }^{8}$ the Association of Southeast Asian Nations ${ }^{9}$ and the League of Arab States. ${ }^{10}$

In addition, human rights texts can be differentiated on the basis of their scope ratione materiae. Comprehensive texts, aiming at a complete list of human rights, ${ }^{11}$ coexist with texts that focus on one category of human rights-generally either civil and political rights or economic, social and cultural rights ${ }^{12}$-and single-issue texts. ${ }^{13}$

Furthermore, with respect to their scope ratione personae, some human rights instruments are universal, ie applicable to all human beings, while

3 eg Universal Declaration on Bioethics and Human Rights (2005).

4 eg ILO Convention No 87 concerning Freedom of Association and Protection of the Right to Organise, ILO Convention No 105 concerning the Abolition of Forced Labour, ILO Convention No 111 concerning Discrimination in Respect of Employment and Occupation ILO Convention No 182 concerning the Prohibition and Immediate Action for the Elimination of the Worst Forms of Child Labour.

5 The main human rights convention of the Council of Europe is the Convention for the Protection of Human Rights and Fundamental Freedoms (1950), known as the European Convention on Human Rights (ECHR).

6 The main human rights standard set by the European Union is the Charter of Fundamental Rights of the European Union (2000).

7 The main human rights convention of the OAS is the American Convention on Human Rights (1969).

8 The main human rights convention of the African Union is the African Charter on Human and Peoples' Rights (1981).

9 ASEAN Human Rights Declaration 2012.

10 Arab Charter on Human Rights 2004

11 eg Universal Declaration of Human Rights, African Charter on Human and Peoples' Rights, Charter of Fundamental Rights of the European Union.

12 eg International Covenant on Civil and Political Rights, International Covenant on Economic, Social and Cultural Rights, European Convention on Human Rights, European Social Charter (1961 and 1996), American Convention on Human Rights, Additional Protocol to the American Convention on Human Rights in the Area of Economic, Social and Cultural Rights (1999).

13 eg Convention Against Torture, International Convention for the Protection of All Persons from Enforced Disappearance, Convention on the Elimination of All Forms of Racial Discrimination, European Convention for the Prevention of Torture and Inhuman or Degrading Treatment or Punishment (1987), Council of Europe Convention on Action against Trafficking in Human Beings (2005), Council Of Europe Convention On Preventing And Combating Violence Against Women And Domestic Violence (2011), Inter-American Convention on the Prevention, Punishment and Eradication of Violence against Women (1994), Inter-American Convention to Prevent and Punish Torture (1985), Inter-American Convention on Forced Disappearance of Persons (1994). 
others have a specific target group, eg women, ${ }^{14}$ children, ${ }^{15}$ persons with a disability, ${ }^{16}$ or members of minority or indigenous groups. ${ }^{17}$

Also, a distinction can be made based on the legal force of the instruments. While numerous human rights norms-constitutions, treaties, customary law-are binding, human rights have also been included in formally non-binding soft law-eg declarations and resolutions-that may nevertheless have strong moral or political force, and even acquire, in the words of the International Court of Justice a 'normative value'. ${ }^{18}$

Finally, there is a great variety among the monitoring mechanisms that accompany binding human rights instruments: these range from judicial control by supranational courts-the European Court of Human Rights, the Inter-American Court of Human Rights, the African Court of Justice and Human Rights - to quasi-judicial control—individual complaints examined by expert committees ${ }^{19}$ - to other forms of expert control and political control-reporting procedures, ${ }^{20}$ special rapporteurs, etc.

While each of these sources is internally coherent and each monitoring body has developed its own broadly consistent case law using its own interpretation tools, the picture as a whole is rather complex. It is a reality of legal pluralism (Berman 2007), which can be experienced as a mega-mall in which rights-holders can go 'forum shopping', thus benefiting from the diversity of norms, yet also as a labyrinth in which they-and their rightsmay get lost. It is a polyphony that may produce a rich harmonious sound

14 eg Convention on the Elimination of All Forms of Discrimination Against Women, Protocol to the African Charter on Human and Peoples' Rights on the Rights of Women in Africa (2003).

15 eg Convention on the Rights of the Child, African Charter on the Rights and Welfare of the Child (1990), Inter-American Convention on International Traffic in Minors (1994).

16 eg Convention on the Rights of Persons with Disabilities.

17 eg Declaration on the Rights of Persons Belonging to National or Ethnic, Religious and Linguistic Minorities (1992), Council of Europe Framework Convention for the Protection of national Minorities (1995), United Nations Declaration on the Rights of Indigenous Peoples (2007).

18 International Court of Justice, Legality of the Threat or Use of Nuclear Weapons, Advisory Opinion, 8 July 1996, ICJ Reports 1996, 226, at 254, $\mathbb{S} 70$.

19 eg the individual complaint procedures before some of the UN treaty monitoring bodies: the Human Rights Committee, the Committee Against Torture, the Committee on the Elimination of Discrimination Against Women, the Committee on the Elimination of Racial Discrimination, the Committee on Economic, Social and Cultural Rights, the Committee on the Rights of Persons with Disabilities and the Committee on Enforced Disappearances; also the collective complaint procedure before the European Committee on Social Rights, and the procedures before the African Commission on Human and Peoples' Rights and the Inter-American Commission on Human Rights.

20 Self-reporting followed by discussion of the report by an expert body may be considered the standard international human rights monitoring procedure on account of its wide use at the global as well as regional levels (Smith 2012: 154). 
that strongly gets a message across, yet may also be a cacophony in which we hear a lot of noise-or noises-but cannot distinguish a clear melody.

\section{TOWARD AN INTEGRATED PERSPECTIVE OF INTERNATIONAL HUMAN RIGHTS LAW}

Academia has a tendency toward specialisation. As the field of human rights law has emancipated, general human rights experts have largely been replaced by experts in, for example, 'children's rights' or 'women's rights' or 'minorities', or experts in the European Convention or the UN system, or in one specific freedom, such as press freedom or non-discrimination, privacy or religious freedom. While this has brought the discipline to a higher level, it has also contributed to creating a fragmented, compartmentalised view of human rights law.

I submit that our interest in the trees should not make us forget to study the forest. I argue that it is highly relevant for scholars of human rights law to study human rights law as an integrated whole: looking at, among other things, issues of consistency and alignment as well as divergence across the different layers of human rights law, at gaps in the overall protection system, and at all kinds of cross-cutting or isolated dynamics. This is relevant both from a bottom-up perspective and from a top-down perspective.

First of all, the study of human rights law as an integrated whole is relevant from the bottom-up perspective of the users of human rights law (Desmet 2014). When I use the term 'users' of human rights law, I mean in the first place the individuals and entities that are the subjects of human rights law, the rights-holders, who are at risk of potential violations, or who have already suffered violations. Yet I include under this term also the public authorities and other duty-bearers under human rights norms, because the point I want to make applies to them as well. The point is that users of human rights law are confronted simultaneously with all of these human rights provisions. To any particular situation, a dozen relevant human rights sources may apply. Hence, in my point of view, it is highly relevant to look at this complex human rights architecture through the lens of its users. This means that we should not just study separate human rights norms or mechanisms, but that we should also pay attention to their simultaneous application, and examine what that implies for the users of human rights law, and how these users deal with that reality of 'internal' legal pluralism.

The study of human rights law is relevant also from a top-down perspective, in the sense that it resonates with some of the central principles of human rights law, in particular the principles of universality and indivisibility of human rights. These two central dogmas of international human rights law appear to plead in favour of an integrated perspective of human 
rights that takes into account all human rights norms relevant in a particular situation; as well as taking into account the human rights of all rights-holders whose rights are affected by a particular situation. Universality means that all people have all human rights. Indivisibility and interdependence means that human rights are a package deal and that there is no hierarchy within human rights. Together, they require that all human rights should carry the same weight, and that they should be read together, strengthening each other. The reality of human rights implementation is, however, often far removed from these principles: cases involving multiple human rights are routinely examined through the lens of one human right only; and the invoking of multiple norms in a single situation remains the exception rather than the rule.

1. Inconsistencies within International Human Rights Law: The Case of Legal Pluralism

When one adopts this holistic, integrated view of international human rights law, one cannot escape the finding that there are a number of inconsistencies within international human rights law taken as a whole. Those may be the result of deliberate choice or instead the unplanned result of the uncoordinated growth of international human rights law. They may create opportunities for rights-holders trying to obtain human rights justice, as well as for human rights duty-bearers trying to duck their obligations. And they may carry a number of risks: the risk of suboptimal human rights protection, the risk of unequal standards of protection, and the risk of lack of legal certainty.

One such inconsistency concerns the attitude of international human rights law towards the recognition of legal pluralism, in the sense of an official legal system making room for a system of 'tradition-based law', a term which I intend to cover indigenous law, customary law as well as religious law. As the discussion that follows will show, there is one layer or field of international human rights law that considers state recognition of tradition-based law as mandatory and non-recognition as a violation of human rights (section 3.1 below). And there is another layer or field of international human rights law that considers such state recognition of tradition-based law as a violation of human rights (section 3.2 below). Human rights law as a whole thus at the same time mandates state organisation of legal pluralism and bans it. The remainder of this chapter will discuss the inconsistent attitude of international human rights law as a whole towards legal pluralism as a case study illustrating the dynamics and consequences of the internal plurality that characterises international human rights law. After discussing each of the above-sketched human rights approaches to legal pluralism in turn, we will examine the implications of this normative inconsistency. 


\subsection{A Right to Legal Pluralism: Indigenous Peoples’ Rights}

The first approach within international human rights law, mandating recognition of traditional law, and hence mandating the recognition and organisation of legal pluralism by the state, is found in the universal regime governing the rights of indigenous peoples. This is laid down in ILO Convention 169 (1989) concerning Indigenous and Tribal Peoples in Independent Countries and in the United Nations Declaration on the Rights of Indigenous Peoples (2007).

The ILO Convention grants indigenous peoples the right to retain their own customs and institutions (Article 8(2)), and mandates state respect for 'the methods customarily practised by the peoples concerned for dealing with offences committed by their members' (Article 9(1)). Both provisions precondition these rights on compatibility with national law and international human rights. In the same vein, the UN Declaration states that: ' $\mathrm{I}]$ ndigenous peoples have the right to promote, develop and maintain their institutional structures and their distinctive customs, spirituality, traditions, procedures, practices and, in the cases where they exist, juridical systems or customs, in accordance with international human rights standards' (Article 34).

At the universal level, and in the specific context of indigenous peoples, there is thus unambiguous recognition of a human right to traditional law. This is a collective human right that belongs to a people as a collective entity (Anaya 2007). It is a fully fledged right, which entails both a freedom from interference as well as a number of positive state obligations. As is common in human rights law the freedom from interference that this right entails is not absolute. In particular, the drafters of these international texts on indigenous rights have foreseen that there might be situations in which the collective rights of indigenous peoples enter into conflict with individual human rights-which may be the rights of individual members of an indigenous people or of individuals who do not belong to the indigenous people. Both texts give priority to the individuals' human rights in such situations. A number of positive state obligations that have been specifically included in the UN Declaration relate to the implications of a state recognising traditional law next to state law and organising a system of legal pluralism. They include the duty to resolve conflicts between legal systems, and the duty to give due recognition to indigenous law in a number of procedures of state law (Articles 27 and 40 UN Declaration).

In the field of indigenous peoples' rights, human rights norms thus require states to recognise certain realities of legal pluralism and to engage with these realities. It has been argued that this is a significant innovation in international human rights law, as it 'challenges the primacy and sphere of state governing authority in a much more fundamental sense than classic individual rights' (Anaya 2007: 8). This is not a small thing, and its significance is increased by the fact that the UN Declaration on the Rights of 
Indigenous Peoples is one of the most recent normative human rights texts at the universal level, and that it was adopted overwhelmingly by the world community. $^{21}$

Yet these novel ideas that challenge the centrality of the state have notas yet-penetrated all layers of international human rights law. As will be discussed below, in another room of the house of human rights, different standards apply, which not only do not mandate state recognition and organisation of legal pluralism, but which even go so far as to ban it, labelling it a human rights violation.

\subsection{A Ban on Legal Pluralism in the Name of Human Rights: The Refab Case}

This other room or other field is that of the Council of Europe human rights protection system, and more specifically the case law of the European Court of Human Rights, applying the European Convention on Human Rights. The approach of the European Convention system to any human rights matter is an important fact within international human rights law as a whole. The European Court of Human Rights is the oldest supranational human rights court, it has by far the largest body of case law of any supranational human rights body, and it is based in a region with a long democratic tradition. It is therefore not surprising to find that the Court and its case law have become reference points within the global human rights project, also beyond Europe.

When it comes to the European Court of Human Rights' position on state recognition of legal pluralism, the relevant case law is not extensive. There have been a number of cases in which the Court-or the former Commission ${ }^{22}$-dealt with the consequences of legal pluralism, eg cases involving polygamy among immigrants in the UK, ${ }^{23}$ Roma marriage in Spain, ${ }^{24}$ informal Islamic marriage in Turkey, ${ }^{25}$ or the enforcement in an Italian state court of a judgment of a religious tribunal of the Catholic church. ${ }^{26}$

21 The Declaration was adopted with an affirmative vote of 144 states in the UN General Assembly. Only four countries-the United States, Canada, Australia and New Zealandvoted against it, while Azerbaijan, Bangladesh, Bhutan, Burundi, Colombia, Georgia, Kenya, Nigeria, Russia, Samoa and Ukraine abstained.

22 Until the entry into force of the 11th additional protocol to the European Convention on Human Rights in 1999, the Convention system was based on two bodies, the European Commission on Human Rights (ECmHR) and the European Court of Human Rights (ECtHR). Individuals did not have direct access to the Court, but had to apply to the Commission. The Commission issued decisions on admissibility and reports on the merits of cases.

23 ECmHR, application no 19628/92, Bibiv United Kingdom, 29 June 1992 (dec).

24 ECtHR, application no 49151/07, Muñoz Diaz $v$ Spain, 8 December 2009.

25 ECtHR (Grand Chamber), application no 3976/05, Şerife Yiğit v Turkey, 2 November 2010.

26 ECtHR, application no 30882/96, Pellegrini v Italy, 20 June 2001. 
Yet only one case addressed the recognition of legal pluralism and its relationship to human rights as such, the case of Refah Partisi $v$ Turkey. ${ }^{27}$ This case will be discussed in some detail in what follows, to the extent that it addresses the issue of legal pluralism. It is an important case, as it was adopted by a unanimous Grand Chamber of 17 judges. The case concerned the forced dissolution of a political party, at that time the biggest party in the Turkish parliament, on the ground that it was 'a centre of anti-secular activities'. This accusation relied on three arguments, one of which concerned the allegation that Refah intended to introduce a system of legal pluralism in Turkey. The other arguments concerned the allegation that Refah would-within this context of legal pluralism-introduce sharia law in Turkey and the allegation that Refah members had suggested that they might use violence to reach their political objectives.

In the Refah judgment, the Court held in quite absolute terms that both the concept of institutionalised legal pluralism and sharia law as such violated human rights. Unfortunately, with respect to each of these far-reaching pronouncements, one cannot escape the impression that the Court did not rely on sufficient expert knowledge and that it did not thoroughly think through the consequences of its rulings. Although a lot can be said about the Court's inappropriate statements about sharia law in the Refah judgment, ${ }^{28}$ this chapter will focus on what it said about legal pluralism.

The allegation that the Refah party intended to 'set up a plurality of legal systems' was based on two quotations from speeches of party leader Necmettin Erbakan: ${ }^{29}$

There must be several legal systems. The citizen must be able to choose for himself which legal system is most appropriate for him, within a framework of general principles. ... The right to choose one's own legal system is an integral part of the freedom of religion'.

and

When we are in power a Muslim will be able to get married before the mufti, if he wishes, and a Christian will be able to marry in church, if he prefers.

Hence the case did not address a situation in which a state actually recognises or organises legal pluralism. ${ }^{30}$ Nor was there any concrete plan in

27 ECtHR (Grand Chamber), applications nos 41340/98 41342/98 41343/98 41344/98, Refah Partisi v Turkey, 13 February 2003.

28 The Court stated in general terms that 'sharia is incompatible with the fundamental principles of democracy', and described sharia as 'stable and invariable', and claimed that 'principles such as pluralism in the political sphere or the constant evolution of public freedoms have no place in it' (Refab judgment, para 123). These statements are at odds with how (Western) experts of Islamic law describe sharia, eg Otto (2011).

29 Refah Partisi $v$ Turkey, para 28.

30 Such situations are rare in the Council of Europe Member States. An example, also relating to Islamic law, are the Mufti jurisdictions operating among the Muslim/Turkish minority in western Thrace (Greece). 
this sense, as this issue was not included in the party's constitution or programme. Yet what matters for our purpose is that the Court saw sufficient evidence of an intent in this sense, and expressed a clear opinion on the matter. The Court concluded that 'a plurality of legal systems, as proposed by Refah, cannot be considered to be compatible with the Convention system'. ${ }^{31}$ In other words, in the eyes of the European Court of Human Rights, legal pluralism is by definition at odds with human rights.

The Court interpreted Refah's point of view in a rather radical way, stating that:

[It] would introduce into all legal relationships a distinction between individuals grounded on religion, would categorise everyone according to his religious beliefs and would allow him rights and freedoms not as an individual but according to his allegiance to a religious movement. ${ }^{32}$

That is a remarkable starting point, given the fact that neither the application of legal pluralism to all legal relationships nor the categorisation of all individuals can be directly derived from Erbakan's words. Practice shows that where institutionalised legal pluralism exists, it is generally limited to certain parts of the law, usually in the sphere of family law. ${ }^{33}$ Moreover it may be organised in such a way that next to tradition-based law, there is a neutral option under state law, which can be opted for by believers and non-believers alike. ${ }^{34}$ In addition, the same individual may rely for certain matters and in certain circumstances on tradition-based law, while preferring state law for other matters or at other times. This is the well-known phenomenon of 'forum shopping'. ${ }^{35}$ There are, however, systems that assign individuals to ethnic or religious categories without giving them such a freedom of choice. ${ }^{36}$ I submit that this is a crucial variable in discussions about the recognition of legal pluralism from a human rights point of view. A mandatory system may offer stronger protection to collective cultural or religious rights, but appears hard to reconcile with individual human rights, in particular with autonomy rights and individual religious freedom, whereas no such a priori conclusion can be drawn with regard to a system that allows for free choice. It is therefore astonishing that the European Court of Human Rights entirely ignores the latter category, and appears to assume automatically that any system of organised legal pluralism must be

31 Refah Partisi $v$ Turkey, para 129.

32 ibid.

33 This is, for example, the case in India, which recognises several types of religious family law (for Hindus, Muslims, Christians and Parsi). See Solanki (2011).

$34 \mathrm{cf}$ the campaign for the recognition of Muslim personal law in South Africa (conducted amongst others by feminists), in a context that also recognises/regulates customary marriage, in addition to providing for civil marriage. See Amien (2010).

35 See Hoekema (2008: 3).

36 In Malaysia, for example, Muslims do not have the possibility to opt for the general legislation that is valid for non-Muslims. See Hussain (2011: 380-81). 
a mandatory system. This is especially remarkable given the fact that the quotations from Erbakan that form the basis of the whole discussion seem to emphasise free choice.

In support of its conclusion that setting up a plurality of legal system is incompatible with human rights, the Court advances two arguments. The first argument is about state monopoly of the law as a requirement for human rights protection (section 3.2.1 below). The second argument considers legal pluralism as inherently discriminatory (section 3.2.2 below). In what follows, the validity of these arguments will be critically assessed.

\subsubsection{State Monopoly of the Law as a Requirement for Human Rights Protection}

In the first place, the Court refers to the obligation of a state 'to ensure that everyone within its jurisdiction enjoys in full, and without being able to waive them, the rights and freedoms guaranteed by the Convention'. ${ }^{37}$ The Court states that this role of the state would be undermined by a system of institutionalised legal pluralism, because it would oblige individuals to obey, not rules laid down by the State in the exercise of its above-mentioned functions, but static rules of law imposed by the religion concerned'. ${ }^{38}$

This argument is problematic. To start with, it is not clear what the Court means by 'enjoy human rights in full'. The Convention rights allow for restrictions and the role of the Court is precisely to distinguish between acceptable and unacceptable restrictions. Restrictions based on religious rules are treated in the same way as other restrictions. What the Court does not take into consideration is that recognising legal pluralism, and in particular making room for religious law in this context, can be one way of striving for the 'full enjoyment of human rights'. Indeed, institutionalised legal pluralism is regularly defended in the name of human rights; these may be collective rights of cultural or religious groups, but also individual rights, in particular the right to live according to the prescriptions of one's religion. ${ }^{39}$ From that perspective one might say that the organisation of legal pluralism does indeed fit within the state's role as 'guarantor of individual rights and freedoms'.

In the Court's reasoning, moreover, there appears to be no room for a scenario in which rules of religious law are in conformity with human rights. Yet the practice of legal pluralism shows that there is no basis for the idea that the recognition of legal pluralism would automatically imply an abdication of the state's obligation to protect human rights. Most individuals

\footnotetext{
37 Refah Partisiv Turkey, para 119.

38 Ibid.

39 cf Meerschaut and Gutwirth (2008: 433).
} 
obey the rules of a number of non-state organisations, both in their private life and in their professional life. This does not undermine human rights, because human rights have been included in constitutions and international conventions, and are therefore on the top of the hierarchy of legal norms, which gives them priority over other rules. One of the reasons for a state to opt for the recognition of legal pluralism is precisely because it allows a state to enforce this priority. Recognition opens the door to regulation of normative orders that exist on the state's territory regardless of recognition. Practice shows that a wide range of techniques are used by states to control the substance as well as the impact of sharia or other tradition-based legal systems in a context of legal pluralism. State law can restrict the spheres of law or the types of disputes to which sharia can be applied. It can codify sharia and in this exercise do away with discriminatory rules through amendment or interpretation. The state can also make secular judges responsible for the application of sharia rules, or it can provide an appeal procedure before state courts. ${ }^{40}$ The Court rightly states that:

Turkey ... may legitimately prevent the application within its jurisdiction of private-law rules of religious inspiration prejudicial to public order and the values of democracy for Convention purposes (such as rules permitting discrimination based on the gender of the parties concerned, as in polygamy and privileges for the male sex in matters of divorce and succession). ${ }^{41}$

Yet it misses the mark when it assumes that this can be realised only by rejecting the recognition of legal pluralism. Instead the opposite is true. Throughout the world, tradition-based legal systems are applied on a large scale regardless of recognition. This means that there are cases in which an important goal such as the fight against discrimination may be better reached through recognition and control than by ignoring the reality of (unofficial) legal pluralism. ${ }^{42}$ There can be no doubt that a state party to the European Convention that opted for the recognition of legal pluralism would be obliged to amend the religion- or tradition-based law it would recognise sufficient to render it compatible with human rights. This may be compared to what happens when a state allows the private sector to organise issues such as education, healthcare or security. Privatisation of these human-rights-sensitive services is not automatically at odds with human

40 For examples, see Otto (2011)

41 Refah Partisiv Turkey, para 128.

42 The Court's case law with respect to Turkey offers an example: the case of Şerife Yiğit $v$ Turkey (see above) concerns the disadvantages suffered in the sphere of social rights by a widow whose Islamic religious marriage that was not recognised by the state authorities. This case illustrates that despite its lack of recognition, Islamic law is applied in Turkey in the sphere of family law. It also shows that discrimination of women results not necessarily-or not only-from the application of religious law, but may be the result of the state's lack of recognition of religious law. The same point is made with respect to South Africa (Amien 2010). 
rights, yet it requires the state to provide guarantees for human rights protection via, amongst other things, the legal instruments that govern such privatisation and through the exercise of control (De Feyter et al 2005). However, rather than giving states guidance on how to address the reality of legal pluralism in a way that optimises human rights protection, the Court chooses to present a caricature of legal pluralism that ignores the reality on the ground.

\subsubsection{Legal Pluralism as Inherently Discriminatory}

The other argument of the Court considers legal pluralism as inherently discriminatory. The Court states that such pluralism discriminates among individuals as regards their enjoyment of public freedoms and that it is not capable of maintaining

a fair balance between, on the one hand, the claims of certain religious groups who wish to be governed by their own rules and on the other the interest of society as a whole, which must be based on peace and on tolerance between the various religions and beliefs. ${ }^{43}$

This is another example of the Court not taking into account the possibility that the institutionalisation of legal pluralism might be organised on the basis of individual free choice. It seems untenable to hold that there is discrimination against persons who choose to rely on Islamic law rather than state law, especially since such choice is the expression of their religious freedom, which is itself a Convention right. ${ }^{44}$

Assuming that the balancing between religious rights and other human rights in a context of legal pluralism leads to different levels of human rights protection within the same state, the question arises whether this is unacceptable in principle, as the Court maintains. In that respect it is useful to point out that other, widely accepted, institutional arrangements lead to the same result, ie different levels of human rights protection because of different legal regimes applying within a state. One can think in particular of the impact of federalism on the enjoyment of human rights. It is not uncommon in federal states that individuals enjoy different levels of human rights protection depending on where they happen to live. Same-sex marriage is allowed in some US states but not in others, and the same holds

43 Refah Partisi $v$ Turkey, para 119.

44 cf the Court's statement in the 'face veil ban' case of SAS $v$ France (Grand Chamber), 1 July 2014, para 119: 'The Court takes the view, however, that a State Party cannot invoke gender equality in order to ban a practice that is defended by women-such as the applicantin the context of the exercise of the rights enshrined in those provisions, unless it were to be understood that individuals could be protected on that basis from the exercise of their own fundamental rights and freedoms.' 
for the death penalty. Likewise, teachers can wear an Islamic headscarf in some German Länder but not in others. Foreigners migrating to Belgium have to take mandatory integration classes in Flanders, but not in Wallonia. Moreover, powers in a federal system are not by definition based (only) on territorial criteria. In Belgium, some inhabitants of Brussels are part of the Flemish community, others of the French community. If the Flemish parliament decides to ban religious dress in schools, while the French Community assembly allows such dress, children and teachers in Brussels would enjoy different levels of protection of their religious freedom depending on the language of their schooling. Would the European Court of Human Rights in that hypothetical situation also maintain that 'such a difference in treatment cannot maintain a fair balance between, on the one hand, the claims of certain [linguistic] groups who wish to be governed by their own rules and on the other the interest of society as a whole, which must be based on peace and on tolerance between the various [linguistic] communities'? ${ }^{45}$

Given the continuum between federalism and legal pluralism, ${ }^{46}$ an a priori rejection of the recognition of legal pluralism on grounds of discrimination is not tenable unless one also rejects all types of federalism in which the power of the federated entities impacts on fundamental rights protection.

\subsubsection{Opposite Approaches to Legal Pluralism}

While the reasoning of the European Court of Human Rights in the Refah judgment is vulnerable to criticism, it has undeniably strong authority. As a fairly recent judgment, which was adopted by a unanimous Grand Chamber, it is not likely to be overruled in the near future. Hence international human rights law taken as a whole includes two diametrically opposite approaches to state recognition and organisation of legal pluralism. Within the universal system for the protection of indigenous peoples' rights, state recognition and organisation of legal pluralism is mandatory as a matter of human rights law. Yet within the regional system of the Council of Europe, state recognition and organisation of legal pluralism is considered to be by definition a human rights violation, at least if the broad statements of the Court in the Refah judgment are to be taken at face value. In what follows, we will examine how to deal with this internal inconsistency of international human rights law.

45 Refah Partisiv Turkey, para 119

46 It is submitted that federalism and legal pluralism are not two entirely different things, but rather are part of a continuum of group-based rights concerning cultural/religious identity and self-determination. For example, for Kymlicka, both federalism and the recognition of tradition-based family law are types of self-government rights, which he considers to be one of three types of group-differentiated rights for cultural groups (Kymlicka 2005). It has to be acknowledged, however, that federalism is not always an expression of self-determination of cultural groups. 


\subsection{Dealing with Inconsistency}

Can international human rights law at the same time mandate the recognition of legal pluralism and oppose it? Do such internal contradictions threaten the sustainability of international human rights law and undermine its force and credibility? In what follows, several lines of arguments that may be advanced to soften or nuance the normative contradiction we observed will be examined on their merits.

\subsubsection{European Exceptionalism}

One way of reconciling the apparently contradictory norms might be to state that Europe does not participate in the global consensus in favour of the recognition of legal pluralism. However, this point cannot be sustained if one looks at the positions of Council of Europe Member States with respect to the universal norms on the rights of indigenous peoples. Among the 22 states that ratified ILO Convention 169, there are four Council of Europe Member States (the Netherlands, Denmark, Norway and Spain). As for the UN Declaration, most Council of Europe Member States were among the large majority that voted in favour at the UN General Assembly. None was among the four dissenters and two states (Azerbaijan and Russia) were among the 11 abstentions.

Hence it is clear that the internal contradiction within international human rights law cannot be characterised as a divergence between a universal standard and a European standard. At least as far as indigenous peoples' rights are concerned, the Member States of the Council of Europe are part of the global consensus that supports a collective right to state-organised legal pluralism.

\subsubsection{A Pragmatic Users' Perspective}

Another way of solving the matter might be to focus on the fact that the universal norm applies specifically to indigenous peoples and does not take a position on the recognition of legal pluralism beyond that specific context. As there are not so many issues concerning indigenous peoples in Europe, ${ }^{47}$ and as these issues seem so far not to have included claims for the recognition of indigenous law, one might argue that in practice, at the level of the human rights users, actual conflicts between contradictory norms of international human rights norms do not occur. However, this position may be carrying pragmatism a little too far for most tastes. Moreover, even within

\footnotetext{
47 This is linked to the fact that there are not so many indigenous peoples in Europe. Yet there are some, in particular the Sami in Scandinavia, the Nenet in Siberia, the Komi peoples in the Urals, and the Circassians in the North Caucasus.
} 
its pragmatic logic it may be problematic, as it relies on ostrich politics. Indeed, one should not exclude the possibility that any of Europe's indigenous peoples might in the future claim recognition of some of its indigenous law. If the Sami of Norway claim recognition of their indigenous law, the Norwegian state would be legally bound under ILO Convention 169, and politically bound under the UN Declaration, to grant that claim. Yet at the same time, it would be prohibited from doing so on the basis of the European Convention on Human Rights, as interpreted by the European Court of Human Rights in its Refah judgment.

\subsubsection{Drawing a Line Between Religion and Culture}

As a third option, one may consider a restrictive reading of the Refah ruling, focusing on the fact that the case is about religious law. The European Court of Human Rights manifestly does not want to make room for religious groups to have their own norms, but, so the argument would go, it might think differently about norms based on culture and tradition as is the case for indigenous peoples. In terms of legal interpretation, that would be a stretch and a twist, as the Court's arguments-relying on the importance it attaches to the state monopoly of the law and of equal protection of the human rights of all citizens - apply prima facie regardless of whether one deals with norms of religious or cultural origin. Yet such restrictive interpretation is not unthinkable, as the language of the Court does refer to religion. However, from an anthropological perspective, drawing a clear line between cultural and religious norms would be hard to sustain. This is so on the one hand because 'religious' rules are strongly intertwined with tradition and culture, and on the other because indigenous norms often carry spiritual and religious meanings. Hence an approach that relies on a black-and-white dichotomy between religion and culture would misrepresent reality and would therefore be viable only by resorting to manipulations that are not compatible with legal certainty.

\subsubsection{Distinguishing Minority, Majority and Indigenous Peoples' Claims}

Another distinction that could be made between the rights of indigenous peoples and the Refah case is that the latter deals with the rights of the majority population in Turkey. It may be argued that the claim for the accommodation of the cultural particularities of a minority group that has known a history of discrimination and whose traditions may be threatened with disappearance is much stronger than that of the members of the majority culture or religion. This does indeed seem to be the overall tendency in international human rights law, in particular in the field of culture, where the right to live according to one's culture appears to be entrenched only for 
minorities. Moreover, the overall layout of international human rights law also shows that among minority peoples, indigenous peoples are singled out for special protection to an extent that goes much beyond what is provided for minorities in general. Hence it might be argued that it is coherent to restrict the right to recognition of legal pluralism to indigenous peoples only. However, upon closer scrutiny this argument is quite problematic. In the first place, this distinction does not have a basis in the Refah judgment, which makes claims of a general nature. It could in principle have argued that the accommodation of Muslim personal law in Turkey would be undesirable because it might affect the large majority of the population. ${ }^{48}$ But it did not do so. Even if we place this fact between brackets and work with the hypothesis that in a future case based on an indigenous claim the Court might wish to distinguish that case from Refah, it might be difficult to do so on the basis of presumed unique characteristics of indigenous peoples. While there are good reasons to differentiate between the rights of indigenous peoples and other peoples with respect to those aspects that relate to the distinguishing characteristics of indigenous peoples-in particular their relationship to their lands-such good reasons do not support all differentiations existing today. When it comes to claims for the recognition of tradition-based law, one cannot get around the similarities between indigenous law and customary law of minority_or indeed majority-peoples. ${ }^{49}$ Would it then not be discrimination, as well as an affront to the principle of universality of human rights, to grant rights to recognition of legal traditions only to indigenous peoples? By way of justification for such unequal treatment, reference to a history of discrimination will not do, as many minorities that are not indigenous peoples have suffered similar histories, and as in many cases majority peoples would likewise be able to argue that their legal traditions were suppressed during colonialism.

\section{CONCLUSION}

When we analyse international human rights law as an integrated whole and focus on its pluralist nature, one approach may be seen as concentrating on drawing normative conclusions from such analysis, with a goal of optimising human rights protection. From that perspective, I conclude that the normative contradiction highlighted in this chapter is indeed problematic,

48 It could have argued, for instance, that this might create pressure to opt for Muslim personal law rather than civil law: cf its arguments with respect to the Islamic headscarf in a university context, in Leyla Şahin v Turkey (Grand Chamber, application no 44774/98, 10 November 2005) para 115.

49 cf Glenn's category of the 'chtonic legal tradition', which includes both the law of indigenous peoples around the world, and customary law in Africa and Asia (Glenn 2004). 
as it cannot be explained in a coherent manner. Moreover the exploration of this contradiction pointed to an area that remains unresolved, namely the position of the universal human rights system vis-à-vis the recognition of legal pluralism in other situations than that of indigenous peoples. Currently, human rights law at the universal level is silent about this matter. As universal human rights law does not include obligations on the part of states to recognise customary or religious law in their rules on minority rights or religious freedom, there is no ground to claim that a right to such recognition currently exists. Neither is there a ground to claim that such recognition would be considered a violation of human rights.

A universal human right to the recognition of legal pluralism appears unrealistic and probably undesirable. Yet, as such a right has been recognised for one category of peoples, international human rights discourse should be able to offer persuasive arguments justifying such privileged treatment. Moreover, looking at international human rights law as an integrated whole, the position of the European Court on Human Rights on this issue is a problematic one, both because it is grounded on arguments that are not persuasive and because it creates contradictory obligations for some states. Should this position spread to the universal level-for all situations except those involving indigenous peoples - this would be even more problematic, as it would lead to blatant unequal treatment of similar cases. Ultimately, it appears important that all actors that play a role in the human rights enforcement machinery are well aware of the fact that they do not operate in isolation, but rather are part of a global project. Within this global project of universal human rights protection, reflection is needed about the demarcation and the rules of the game to create a sustainable room for divergence and a space for bottom-up dynamics. 
